DOI: $10.6060 / \mathrm{mhc} 150765 \mathrm{~s}$

\title{
The Role of Oxygen in Electrochemical Reduction of Double-Decker Phthalocyaninates of Lanthanides
}

\author{
S. L. Selektor, ${ }^{a}$ A. V. Shokurov, ${ }^{a}$ A. A. Revina, ${ }^{a}$ V. V. Arslanov, ${ }^{a}$ Yu. G. Gorbunova, ${ }^{\mathrm{a}, \mathrm{b}}$ \\ and A. Yu. Tsivadze $\mathrm{a}^{\mathrm{a} b}$
}

Dedicated to Prof. Mir Wais Hosseini, who has made a significant contribution to macroheterocycles chemistry, on the occasion of his anniversary

\begin{abstract}
${ }^{a}$ A.N. Frumkin Institute of Physical Chemistry and Electrochemistry RAS, 119071 Moscow, Russia
${ }^{\mathrm{b}}$ N.S. Kurnakov Institute of General and Inorganic Chemistry RAS, 119991 Moscow, Russia

@Corresponding authorE-mail: sofs@list.ru
\end{abstract}

\begin{abstract}
The influence of air oxygen on the processes of electrochemical reduction of double-decker 15-crown-5 substituted lanthanide phthalocyaninates in solutions and Langmuir-Blodgett films on electrode surfaces was revealed. The multistage nature of the process, associated with formation of the intermediate oxygen-containing complexes of the studied compounds in the presence of atmospheric oxygen, was confirmed by cyclic voltammetry and spectroelectrochemical measurements. It was shown that spectra of the electrochemically reduced forms of complexes coincide with ones obtained via chemical reduction only upon application of extremely negative potentials or in the absence of air oxygen in electrolyte.
\end{abstract}

Keywords: Sandwich phthalocyanine, lanthanide, electrochemistry, Langmuir-Blodgett films, oxygen, electrochemical reduction, cyclic voltammetry, spectroelectrochemistry.

\section{Роль кислорода в электрохимическом восстановлении Авухпалубных фталоцианинатов лантанидов}

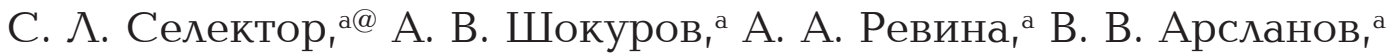 \\ Ю. Г. Горбунова, ${ }^{\mathrm{a}, \mathrm{b}}$ А. Ю. Цивадзе $\mathrm{e}^{\mathrm{a}, \mathrm{b}}$
}

Посвящается профессору Мир Вайсу Хоссейни, внесиему значительный вклаg в химию макрогетероциклов, по случаю его юбилея

\begin{abstract}
${ }^{\mathrm{a}}$ ФБУН Институт физической химии и электрохимии им. А.Н. Фрумкина РАН, 119071 Москва, Россия
${ }^{\mathrm{b}}$ ФГБУН Институт общей и неорганической химии им. Н.С. Курнакова РАН, 119991 Москва, Россия

${ }^{\circledR}$ E-mail:sofs@list.ru
\end{abstract}

\begin{abstract}
В работе было установлено влияние кислорода воздуха на прочессы химического восстановления двухпалубных 15-краун-5-замещенных фталочианинатов лантанидов в растворах и плёнках Лэнгмюра-Блоджетт на поверхности электрода. Мульти-стадийная природа процесса, заключающаяся в образовании промежуточных комплексов, содержащих кислород, была подтверждена с использованием ичилической вольтамперометрии и спектро-электрохимических исследований. Показано, что спектры электрохимически восстановленных комплексов совпадают со спектрами комплексов, полученных химическим восстановлением, только при приложении больших отрицательных потенцииалов или при более низких потенциалах в отсутствии кислорода в электролите.
\end{abstract}

Ключевые слова: Сэндвичевый фталоцианин, лантанид, электрохимия, плёнки Лэнгмюра-Блоджетт, кислород, электрохимическое восстановление, циклическая вольтамперометрия, спектроэлектрохимия. 


\section{Introduction}

Discotic aromatic compounds attract attention of the researchers due to their high tendency to self-assembly into supramolecular level columnar structures, which can act as transport channels of various purposes. Interest to tetrapyrrolic ligands, as great representative of such molecules increases in last decades due to their unique properties such as multistability associated with lability of electronic structure of the macrocycle, formation of complexes with the majority of metals, and also the possibility for fine-tuning of physico-chemical properties of the complexes via introduction of peripheral substituents and axial ligands of various nature. ${ }^{[1-4]}$

Sandwich double- and triple-decker lanthanides complexes are special type of phthalocyanine compounds due to unique electronic, optical, and physico-chemical properties that are determined by strong intramolecular $\pi-\pi$ interactions between ligands. ${ }^{[5-8]}$

Electrochromism, which is characteristic for sandwich lanthanide phthalocyaninates, ${ }^{[9-13]}$ provides ability for their application in production of displays for electronic devices. Some groups note high prospects of employment of large set of electrochemically reversible redox-transitions in sandwich complexes of lanthanides for multibit information recording. ${ }^{[14-18]}$ In this light, phthalocyaninates of lanthanides with variable valence attract great interest due to possibility of realization of additional redox-process associated with change of metal center oxidation state. ${ }^{[18-25]}$

On the other hand, practical application of such compounds requires knowledge on the influence of external factors on properties of redox-processes taking place in these systems. One of such factors is the presence of oxidizers, and, primarily, atmospheric oxygen. Previously, ${ }^{[23]}$ we have proposed that reduction of lanthanide bis-phthalocyaninates in ultrathin films in the presence of dissolved oxygen occurs in a multi-stage manner, and only the first, electrochemical stage of this process, takes place at the redox-transition, observed on the voltammogram.

The present work is devoted to the comparison of electrochemical behavior of solutions and ultrathin films of lanthanide 15-crown-5-phthalocyaninates on air and in inert atmosphere.

\section{Experimental}

The studied double-decker tetra-15-crown-5 substituted phthalocyaninates of lanthanides $\mathrm{Ln}\left(\mathrm{R}_{4} \mathrm{Pc}\right)_{2} \quad(\mathrm{R}=15$-crown-5, $\mathrm{Pc}=$ phthalocyanine) (Figure 1) were synthesized in the laboratory of novel physico-chemical problems of IPCE RAS. ${ }^{[26-29]}$

The monolayers of double-decker lanthanide complexes with tetra-15-crown-5-phthalocyanine were formed from chloroform solutions. Deionized water (resistivity $>18 \mathrm{M} \Omega \cdot \mathrm{cm}, \mathrm{pH} 5.6$ ("Vodolei", produced by "Khimelektronika")) was used as a subphase. Monolayer compression isotherms were obtained using KSV Mini trough (Finland) device, equipped with Teflon Langmuir trough, special hydrophilic barriers, Wilhelmy plate technique for determination of surface pressure, and a device for automated transfer of the monolayers onto solid substrates. Spectral control of the compounds at the interface was carried out using fiber optic UVvis spectroscopy technique, described by us previously. ${ }^{[30]}$ Transfer of the monolayers onto ITO electrodes for electrochemical and spectroelectrochemical measurements was performed according to Langmuir-Blodgett method (vertical transfer) at maintenance of constant surface pressure. Experimental conditions for the transfer were following: room temperature of the subphase, barrier speed $10 \mathrm{~mm} / \mathrm{min}$, surface pressure of $30 \mathrm{mN} / \mathrm{m}$, dipper speed of $5 \mathrm{~mm} /$ min, transfer ratios for the monolayer films was in the range from 0.7 to 0.9 .

Electronic "IPC-compact" potentiostat, developed and produced in IPCE RAS, was used for electrochemical studies by cyclic voltammetry $(\mathrm{CV})$ method and for setting of the potential applied to the electrode with ultrathin films or electrode immersed into solutions of studied compounds in spectroelectrochemical experiments. The measurements were carried out in three-electrode cells with separated anode-cathode volumes. Standard silver/silver chloride
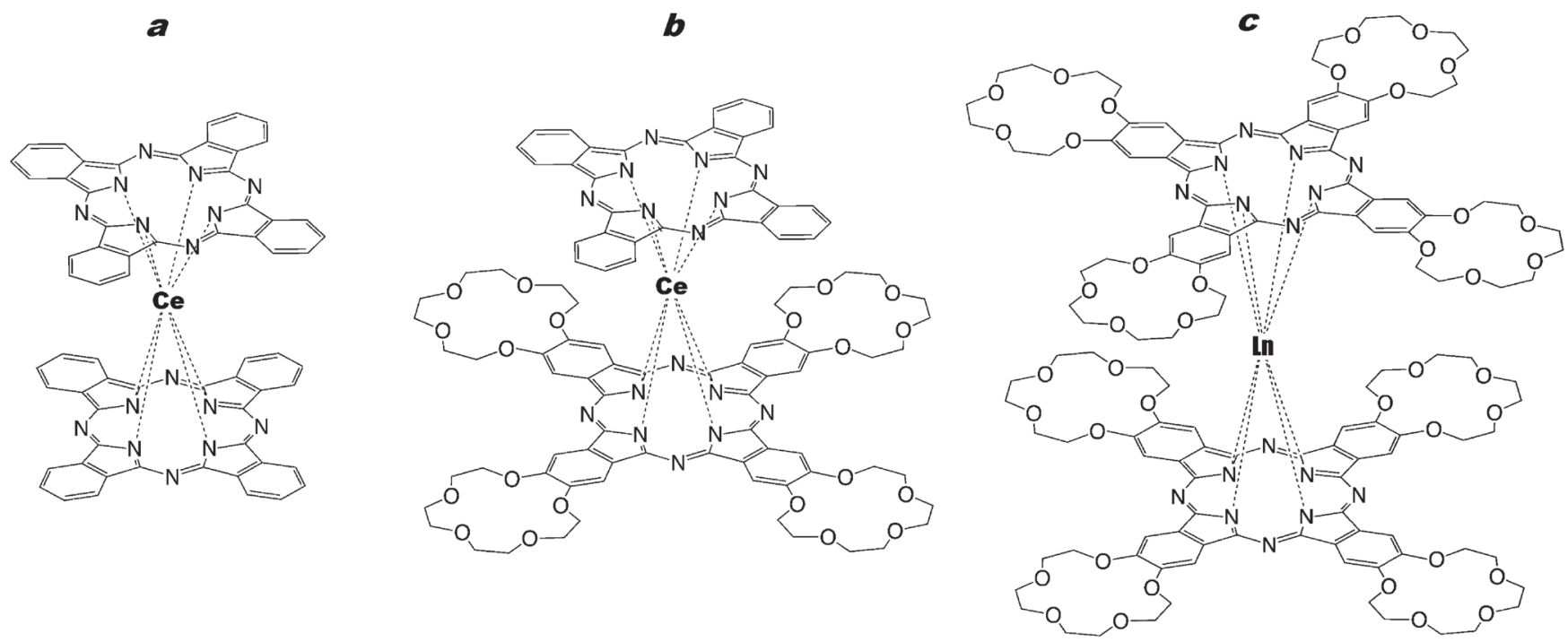

Ln = Pr, Ce, Tb Lu

Figure 1. Sandwich bis-phthalocyaninates of lanthanides: unsubstituted (a); heteroleptic tetra-15-crown-5 substituted (b); homoleptic octa15-crown-5 substituted derivative (c). 
$\left(\mathrm{Ag}^{+} / \mathrm{AgCl}\right)$ electrode was used as a reference electrode in all the cells. Platinum plate electrode acted as an auxiliary electrode. In experiments with Langmuir-Blodgett films (LBF), ITO-substrate with transferred ultrathin film acted as working electrode, measurements were conducted in $0.1 \mathrm{M} \mathrm{HClO}_{4}$ or $\mathrm{KClO}_{4}$ solutions. In the case of electrochemical studies of acetonitrile solutions, platinum mesh was the working electrode, and tetrabutylammonium tetrafluoroborate (Sigma Aldrich) acted as background electrolyte.

$\mathrm{CV}$ curves for ultrathin films were recorded in the potential range from $+1.0 \mathrm{~V}$ to $-0.3 \mathrm{~V}\left(\mathrm{Ag}^{+} / \mathrm{AgCl}\right)$, and for solutions - from $+1.5 \mathrm{~V}$ to $-1.0 \mathrm{~V}\left(\mathrm{Ag}^{+} / \mathrm{AgCl}\right)$ at potential sweep rates from 5 to 100 $\mathrm{mV} / \mathrm{s}$.

UV-vis spectra of the solutions and films on the surface of ITO-electrodes upon application of stepwise changing external potential were recorded in the transmission mode using fiber optic spectrophotometer AvaSpec-2048x64 (Avantes, Netherlands) in the wavelength range of 300-900 nm.

In the case of experiments in inert atmosphere, helium gas was purged through the volume of the electrochemical cell equipped with a water seal for 30-40 minutes in order to replace the oxygen dissolved in the electrolyte. Electrochemical measurements were carried out immediately after the purging, with no gas flow.

\section{Results and Discussion}

Redox properties of the solutions of double-decker homoleptic octa-15-crown-5-phthalocyaninates of lanthanides upon electrochemical and chemical oxidation and reduction were studied on the example of complexes of praseodymium, terbium, and cerium: $\operatorname{Pr}\left(\mathrm{R}_{4} \mathrm{Pc}\right)_{2}, \mathrm{~Tb}\left(\mathrm{R}_{4} \mathrm{Pc}\right)_{2}$, and $\mathrm{Ce}\left(\mathrm{R}_{4} \mathrm{Pc}\right)_{2}$ (Figure $\left.1 \mathrm{c}\right)$.

Special attention was devoted to cerium complexes for which the influence of donor substitutes on the discussed effect was investigated by using unsubstituted and heteroleptic complexes (Figure 1a,b). As it is known, ${ }^{[17-19,21-26]}$ cerium atom in sandwich-type phthalocyaninates can exhibit two oxidation states: +3 , as all the lanthanides and +4 . Special stability of the configuration of the $4 f^{\circ}$ free shell makes tetravalent state of the cerium ion quite stable. In ${ }^{[26]}$ it was shown that cerium is predominantly in +4 state in the chloroform solution of the studied octa-15-crown-5 substituted complex, and the whole complex at this has the following electronic structure: $\mathrm{Ce}^{4+}\left(\mathrm{R}_{4} \mathrm{Pc}^{2-}\right)_{2}$. UV-vis spectral similarity of such homoleptic complex and its heteroleptic analogue (Pc) $\mathrm{Ce}\left(\mathrm{R}_{4} \mathrm{Pc}\right)$, which contains crown ether substituents only in one of the phthalocyanine macrocycles (Figure 1b), indicates that the electronic structure of the heteroleptic complex in the solution can be written in an analogous way: $\left(\mathrm{Pc}^{2-}\right)$ $\mathrm{Ce}^{4+}\left(\mathrm{R}_{4} \mathrm{Pc}^{2-}\right)$. The existence of the dynamic equilibrium between sandwich complexes of tri- and tetravalent cerium in solutions should be noted. ${ }^{[23]}$

The measurements of electrochemical properties of solutions and Langmuir-Blodgett films (LBF) carried out by cyclic voltammetry method have shown that in full accordance to literature data, ${ }^{[31,32]}$ voltammograms of doubledecker complexes of trivalent lanthanides contain two peaks in the range of potentials from -0.5 to $1.0 \mathrm{~V}$, one of which (in the area of $0.3-0.6 \mathrm{~V}$ ) can be assigned to the process of oneelectron oxidation of the phthalocyanine ligand, and another one (in the range of $-0.13-0.00 \mathrm{~V}$ ) - to its one-electron reduction (Figure 2, curve 1). At the same time, CV curve of 15-crown-5 substituted double-decker complexes of cerium, which can change its valence state in such complexes, exhibits three peaks in the same range of potentials (Figure 2, curve 2), one of which, apparently, corresponds to the redox process on the metal center cation. ${ }^{[13]}$ In order to confirm these assignments of $\mathrm{CV}$ peaks, we carried out similar spectroelectrochemical studies of the solutions of some sandwich crown-phthalocyaninates of the few threevalence lanthanides ( $\mathrm{Lu}, \mathrm{Tb}, \mathrm{Pr})$. In these measurements, potentials lying between voltammogram peaks (potentials corresponding to the state after one or another redoxtransition) were chosen as characteristic points.

The results of the measurements, carried out in "open" spectroelectrochemical cells (in the presence of dissolved oxygen), are listed in Table 1. The presented spectral parameters of oxidized forms of the complexes agree well with the literature data on the spectrophotometric titration of the double-decker complexes of praseodymium and cerium by oxidizing and reducing agents. ${ }^{[33]}$ However, it turned out that solution spectra do not assume the shape described in ${ }^{[10,19,26,32-34]}$ characteristic for chemically reduced forms of bisphthalocyaninates under mentioned conditions at reduction potentials. It is well-known, that the absorbance band around $500 \mathrm{~nm}$, which corresponds to the presence of unpaired electron in the complex, and Q-band of the initial form of the complex disappear upon chemical reduction.

As the measurements for open cell with the solution of the sandwich complex of terbium have shown (Figure 3), slow increase of the shoulder around $640 \mathrm{~nm}$ takes place upon application of the potential corresponding to reduced form of the complex (around -0.3 , i.e. more than $0.2 \mathrm{~V}$ below the $\mathrm{CV}$ peak) to the working electrode. At the same time, the band in the area of $500 \mathrm{~nm}$ does not shift and does not significantly decrease in intensity even upon extended exposition of the solution at potential of $-0.3 \mathrm{~V}$. These data explicitly indicate the occurrence of the reaction competing with the "true" reduction of the compound. The same spectral pattern is observed upon electrochemical reduction of the solutions of octa-15-crown-5 substituted complexes of praseodymium and cerium: at potentials from -0.2 to $-0.3 \mathrm{~V}$, shoulder around $625 \mathrm{~nm}$ increases, but intensity of the band around $500 \mathrm{~nm}$ does not decrease.

In other words, spectra of the complexes, recorded at reduction potentials (according to CVA data) significantly differ from the spectra of chemically reduced $\mathrm{Ln}\left(\mathrm{R}_{4} \mathrm{Pc}\right)_{2}$.

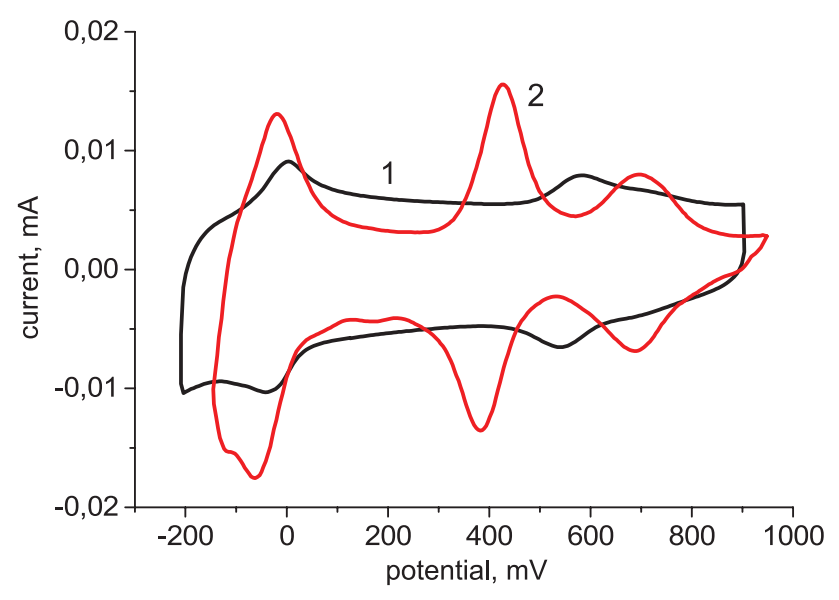

Figure 2. Cyclic voltammograms of LBF of tetra-15-crown-5-bisphthalocyaninates of praseodymium (1) and cerium (2). 
Table 1. Position of the characteristic bands in the UV-vis spectra of $\operatorname{Ln}\left(\mathrm{R}_{4} \mathrm{Pc}\right)_{2}$, acetonitrile solutions, obtained spectroelectrochemically.

\begin{tabular}{ccccc}
\hline $\begin{array}{c}\text { Redox state } \\
\text { Complex }\end{array}$ & $\begin{array}{c}\text { neutral } \\
(+0.2 \mathrm{~V})\end{array}$ & $\begin{array}{c}\text { Red1 } \\
(-0.2 \mathrm{~V})\end{array}$ & $\begin{array}{c}\text { Ox1 } \\
(0.5-0.7 \mathrm{~V})\end{array}$ & $\begin{array}{c}\text { Ox2 } \\
(0.9 \mathrm{~V})\end{array}$ \\
\hline $\mathrm{Lu}\left(\mathrm{R}_{4} \mathrm{Pc}\right)_{2}$ & $664 ; 473$ & $663 ; 622 s h{ }^{*} ; 469$ & $694 ; 628 s h ; 479$ & - \\
$\mathrm{Tb}\left(\mathrm{R}_{4} \mathrm{Pc}\right)_{2}$ & $664 ; 484$ & $665 ; 626 s h . ; 484$ & $665 ; 630 s h ; 495$ & - \\
$\mathrm{Pr}\left(\mathrm{R}_{4} \mathrm{Pc}\right)_{2}$ & $676 ; 501$ & $675 ; 640 s h ; 496$ & $676 ; 636 s h ; 500$ & - \\
$\mathrm{Ce}\left(\mathrm{R}_{4} \mathrm{Pc}\right)_{2}$ & $683+636 ; 474$ & $667 ; 637 s h ; 510$ & $671 ; 636 s h ; 510$ & $760 ; 540$ \\
\hline
\end{tabular}

*here and below: sh. $=$ spectral shoulder

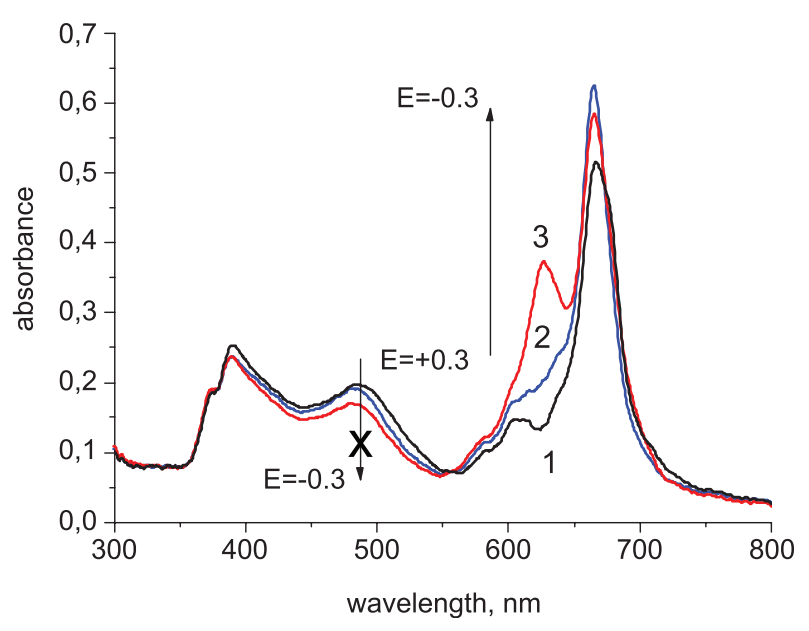

Figure 3. Spectral changes upon electrochemical reduction of the solution of 15-crown-5 substituted double-decker phthalocyaninate of terbium in acetonitrile upon application of potential (1) $+0.3 \mathrm{~V}$, (2) $0.0 \mathrm{~V}$, (3) $-0.3 \mathrm{~V}$. The arrows indicate the direction of the spectral changes upon transition from potential of +0.3 to $-0.3 \mathrm{~V}$.

The form of the spectra corresponding to the spectrum of chemically reduced bis-phthalocyaninates can only be obtained upon application of deep negative potentials (below $-1.2 \mathrm{~V}$ ), i.e. at potentials significantly more negative than the reduction peak in the voltammogram (Figure 4).

It is necessary to emphasize that in all the cases described in literature, spectra of reduced complexes with sharply pronounced non-split short-wavelength Q-band and repressed band around $500 \mathrm{~nm}$ were obtained under strict conditions upon their chemical reduction in the presence of significant excess of the reducing agent ${ }^{[19,26,27]}$ or, as in our experiments, upon very large negative shifts of the potential (below -1 $\left.\mathrm{V}\left(\mathrm{Ag}^{+} / \mathrm{AgCl}\right)\right)^{[10,35-38]}$

However, researchers never attached any importance to this phenomenon. At the same time, observed behavior of the system allows us to assume that reduction of lanthanide bis-phthalocyaninates under considered conditions occurs in a multistage manner, and only the first electrochemical stage of this process occurs at redox-transition observed on voltammogram. The following stages, apparently, take place not by electrochemical pathway, since appearance of the spectra of reduced form of the complexes is not accompanied by the appearance of new peaks on voltammograms.

It should be noted that reduction potentials of lanthanide bis-phthalocyaninates on $\mathrm{CV}$ curves lie in the range of

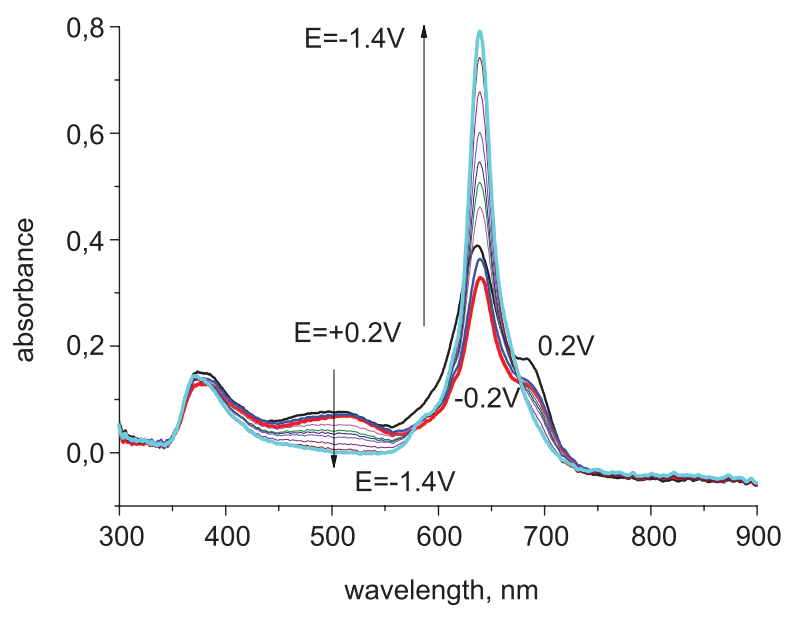

Figure 4. Reduction of the $\mathrm{Ce}\left(\mathrm{PcR}_{4}\right)_{2}$ solution in open cell upon application of deep negative potentials. The arrows indicate the direction of the spectral changes upon transition from potential of +0.2 to $-1.4 \mathrm{~V}$.

potentials of so-called four-electron process - a process of reduction of the air oxygen dissolved in the electrolyte, thus, it was expedient to carry out the comparative analysis of redoxbehavior of the solutions of lanthanide bis-phthalocyaninates in presence of oxygen and in inert atmosphere.

As it was expected, the same spectral changes as upon electrochemical oxidation of the complexes in open cell with free access to air oxygen were observed in experiments in the helium atmosphere. However, spectral changes upon electrochemical reduction of bis-phthalocyaninates in inert atmosphere significantly differed from the process, observed in the open cell: UV-vis spectrum assumed the form corresponding to the chemically reduced state of the phthalocyaninates right after application of the potential of the reduction peak in its voltammogram (Figure 5). In the case of cerium complex, a significant increase of intensity of short wavelength component of Q-band (around $640 \mathrm{~nm}$ ) and simultaneous decrease of intensity of the band around $500 \mathrm{~nm}$ are observed. It is significant that the potential of the formation of "true" reduced form of the studied complexes in the presence of the air oxygen coincides with the potential of the decomposition of known peroxo- and super-oxo-complexes of macrocyclic compounds, and in inert atmosphere the reduction process takes place in total agreement with CV. This allows us to assume that upon electrochemical reduction of solutions of double-decker 15crown-5-phthalocyaninates of lanthanides, air oxygen forms 
some kind of intermediate complexes with them, as in the case of metalloporphyrin reduction in the presence of dissolved oxygen described in ${ }^{[39]}$. In other words, electrochemical reduction takes place through some intermediate process that competes with "true" reduction of the studied macrocyclic compounds. Apparently, this process leads to formation of the compounds of studied phthalocyaninates with dissolved oxygen, as a result of decomposition of which reduced forms of phthalocyaninates that do not contain oxygen are generated at potentials below $-1.2 \mathrm{~V}$.

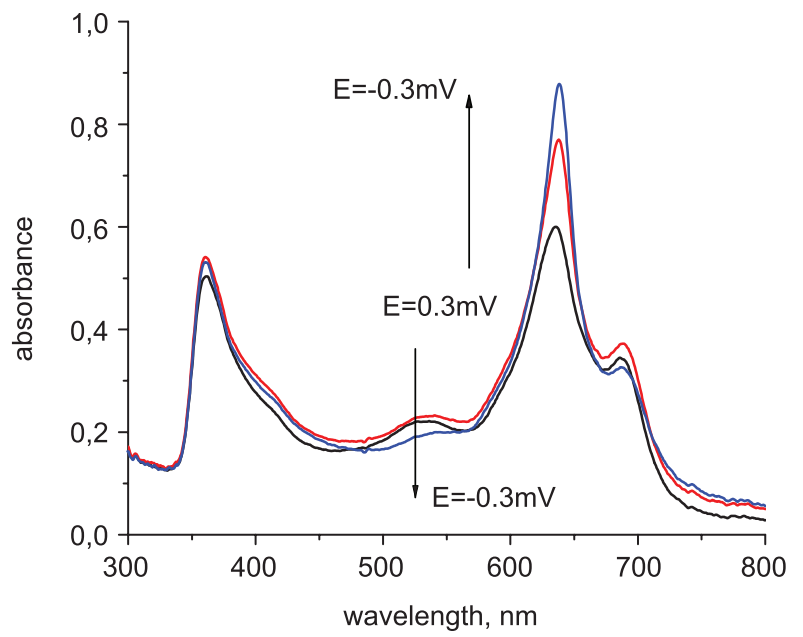

Figure 5. UV-vis spectral changes upon electrochemical reduction of the solution of 15-crown-5 substituted doubledecker phthalocyaninate of cerium in oxygen-free medium upon application of potentials from $+0.3 \mathrm{~V}$ to $-0.3 \mathrm{~V}$.

It is interesting to note that analogous role of the dissolved oxygen in electrochemical processes was observed by us for solutions of the compounds of another class iron(II) clathrochelates. ${ }^{[40]}$

The results obtained should be considered upon investigation of the electrochemical processes occurring in the Langmuir-Blodgett films of the studied compounds. Single-layered films were obtained under conditions described in the experimental section. Figure 6 shows the typical compression isotherms for the studied compounds.

As it was expected, upon reduction of LBF of all the studied complexes (peak in the range from -0.1 to $0.0 \mathrm{~V}$ ), their spectra undergo similar changes (Figure 6,a-c, curves 2): intensity of the Q-band of the neutral green form of bis-phthalocyaninates decreases, and a shoulder around $600 \mathrm{~nm}$ appears and increases with exposition time.

Mathematical expansion of the spectra recorded at potentials below the reduction peak into components with Gauss curve shapes in absorbance-wavelength $\left(\mathrm{cm}^{-1}\right)$ coordinates, allowed us to determine more accurate the position of the new Q-band component. It was found that for all complexes it is located in the range of 610-625 nm.

Linear correlation dependence of the position of the reduction peak in the voltammogram of $\mathrm{Ln}\left(\mathrm{R}_{4} \mathrm{Pc}\right)_{2} \mathrm{LBF}$ on ionic radius of the complex metal center indicates the similarity of the processes, which take place upon electrochemical reduction (Figure 7).

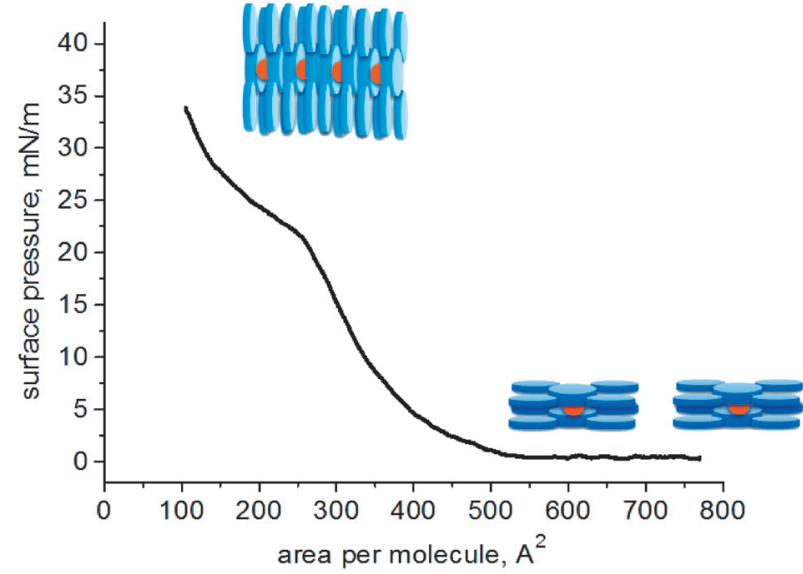

Figure 6. Typical compression isotherm of $\operatorname{Ln}\left(\mathrm{PcR}_{4}\right)_{2}$ monolayers on aqueous subphase. The inset illustrates orientation of the complex molecules during compression.

Spectral changes of the LBF at potentials from -0.2 to $-0.3 \mathrm{~V}$ in the presence of dissolved oxygen described above could be interpreted as a beginning of the reduction of the trivalent lanthanide complexes. However, for any of the studied compounds even extended (up to $20 \mathrm{~min}$ ) exposition of the electrode with the film at potential of $-0.3 \mathrm{~V}$ (more than $0.2 \mathrm{~V}$ below the reduction peak on $\mathrm{CV}$ curve), as in the case of solutions, does not allow one to obtain a spectrum with sharply pronounced non-split short wavelength Q-band and significantly repressed band around $500 \mathrm{~nm}$, which is usually assigned to the reduced double-decker phthalocyaninates of metals in the literature. ${ }^{[10,19,26,27,34-36]}$

Substitution of the working electrolyte $(0.1 \mathrm{M}$ perchloric acid) by $0.1 \mathrm{M}$ solution of potassium perchlorate allowed us to visually confirm the high degree of the completeness of the redox-processes in the films. Change of the electrolyte acidity did not lead to significant changes of the CV curves' shape for LBF of 15-crown-5 substituted bis-phthalocyaninates of lanthanides. For all complexes, spectroelectrochemical behavior of highly ordered films in the salt solution and in perchloric acid differs only in position of the redox-transitions potentials. And in neutral electrolyte, decrease of the observed currents to the values of charging currents is observed even at potentials $0.15-0.20 \mathrm{~V}$ more negative than potential of the first peak on the CV curve (Figure 8), which indicates the completeness of the redoxprocess on the electrode. Moreover, extended (up to $10 \mathrm{~min}$ ) exposition of the electrodes with LBF at potentials more than $0.4 \mathrm{~V}$ below the complex reduction potentials on $\mathrm{CV}$ curve in neutral $\mathrm{pH}$ (in $\mathrm{KClO}_{4}$ solution) does not allow one to obtain a spectrum characteristic for chemically reduced forms of double-decker phthalocyaninates of lanthanides. It is important to underscore that this behavior is in good agreement with data reported in ${ }^{[38]}$, where "true" reduced form of the similar lutetium bis-phthalocyaninate in thin film was obtained in salt solutions only upon application of deep negative potentials $(-1.0 \mathrm{~V})$.

It should be noted that the presence of crown substituents in the complex somewhat hinders the process of formation of the intermediate states of sandwich phthalocy- 

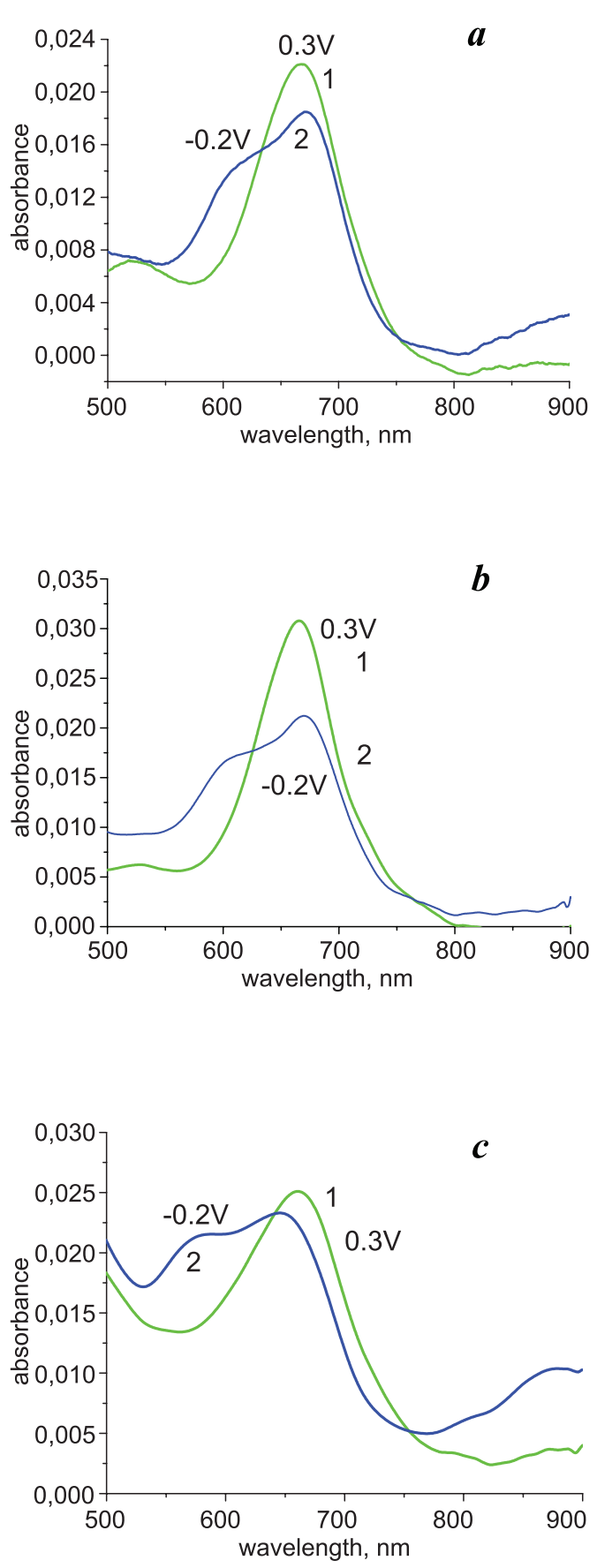

Figure 7. UV-vis spectra of LBF of (a) $\mathrm{Ce}\left(\mathrm{R}_{4} \mathrm{Pc}\right)_{2}$, (b) $\operatorname{Pr}\left(\mathrm{R}_{4} \mathrm{Pc}\right)_{2}$, and (c) $\mathrm{Lu}\left(\mathrm{R}_{4} \mathrm{Pc}\right)_{2}$ in (1) electrochemically neutral state and (2) at potential below reduction peak on $\mathrm{CV}$ curve.

aninates upon electrochemical reduction. Thus, in LBF of octa-15-crown-5 substituted bis-phthalocyaninate of cerium, at potential below complex reduction potential, corresponding spectral changes are much less pronounced than in films of tetra-substituted and unsubstituted analogues (Figure 9). Apparently, this is associated with the screening effect of the donor crown ether groups. However, spectrum, corresponding to chemically reduced form of the complex, cannot be obtained for none of the studied compounds at potentials even $0.3 \mathrm{~V}$ below the left peak on $\mathrm{CV}$ curve.

Detailed studies of the spectral changes of ultrathin films on ITO-electrodes in aqueous solutions of $\mathrm{HClO}_{4}$ in the

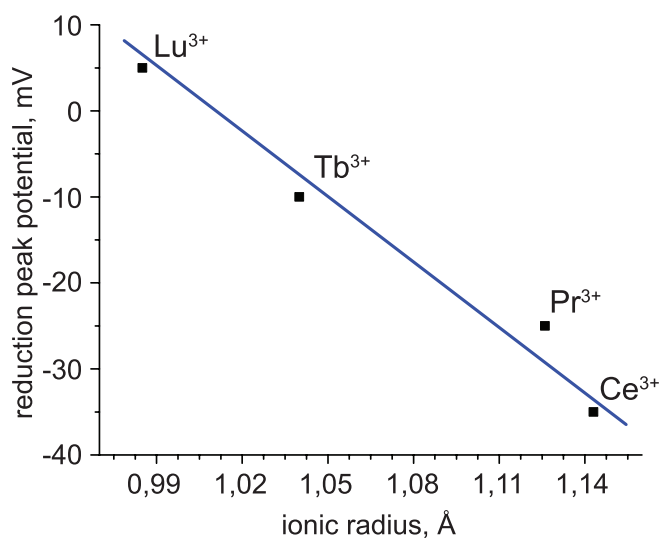

Figure 8. Position of the reduction peaks on CV curves for LBF of homoleptic double-decker 15-crown-5-phthalocyanines of four lanthanide series specimens as a function of ionic radius of the metal center of the complex.

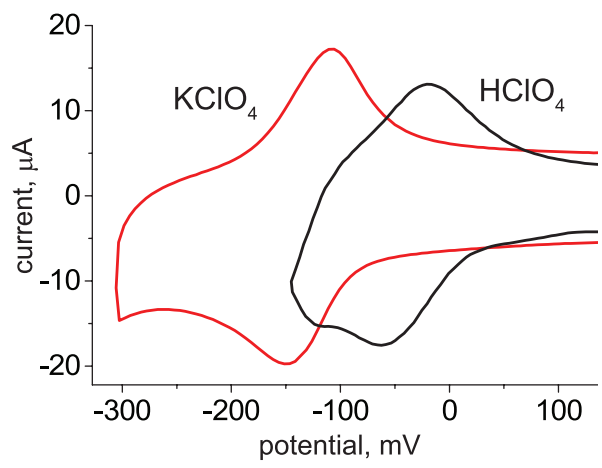

Figure 9. $\mathrm{CV}$ curves in the reduction potential range for LBF of $\mathrm{Ce}\left(\mathrm{R}_{4} \mathrm{Pc}\right)_{2}$ in $0.1 \mathrm{M}$ solution of perchloric acid and in $0.1 \mathrm{M}$ solution of potassium perchlorate.

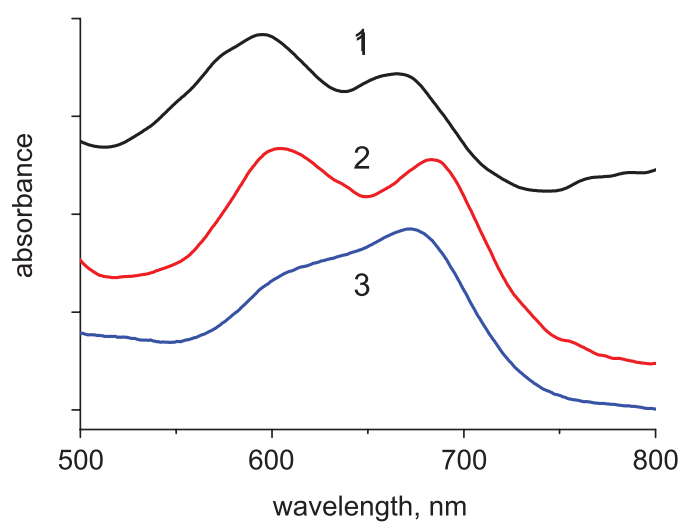

Figure 10. UV-vis spectra of LBF of cerium complexes with various number of crown substituents, obtained upon application of potential of $-0.2 \mathrm{~V}$ for 5 minutes: (1) non-substituted bis-phthalocyaninate, (2) tetra-15-crown-5 substituted bis-phthalocyaninate, and (3) octa-15-crown-5 substituted bis-phthalocyaninate.

range of potentials from $-0.3 \mathrm{~V}$ to $0.2 \mathrm{~V}$ were carried out on examples of LBF of praseodymium and lutetium complexes in open cell. As can be seen from the data of stepwise spectral scanning of the electrode with $\mathrm{LBF}$ of $\mathrm{Lu}\left(\mathrm{R}_{4} \mathrm{Pc}\right)_{2}$ upon slow 
$(5 \mathrm{mV} / \mathrm{s})$ decrease of potential from 0.2 to $-0.3 \mathrm{~V}$ represented in Figure 10, the reduction process is monotonous and leads to changes analogous to the spectral changes observed in solutions.

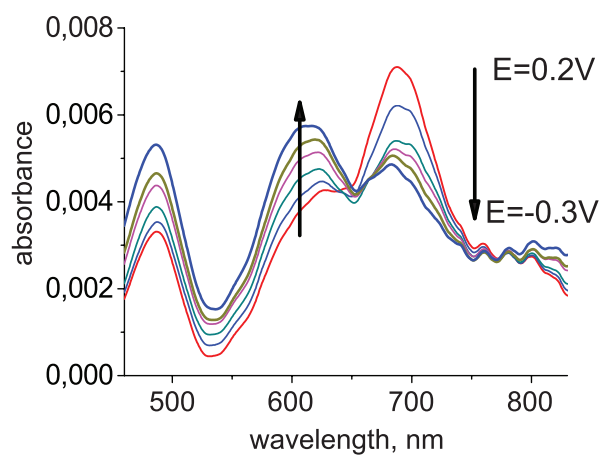

Figure 11. UV-vis spectra of $\mathrm{Lu}\left(\mathrm{R}_{4} \mathrm{Pc}\right)_{2} \mathrm{LBF}$ upon slow reduction in the potential range from 0.2 to $-0.3 \mathrm{~V}$. The arrows indicate the direction of the spectral change upon transition from potential of +0.2 to $-0.3 \mathrm{~V}$.

Spectroelectrochemical studies of LBF in inert atmosphere revealed the same pattern that we observed after helium purging of lanthanide bis-15-crown-5phthalocyaninates solutions. Figure 11 shows spectra of electroneutral form of the $\mathrm{Ce}\left(\mathrm{R}_{4} \mathrm{Pc}\right)_{2}$ complex and spectra recorded at potential of $-0.3 \mathrm{~V}$ in open cell under inert atmosphere. At the same time, UV-vis spectra of the LBF, as in case of solutions, assume the form characteristic for chemically reduced phthalocyaninates upon electrochemical reduction in the absence of oxygen even at potentials of the first peak on CV curve. Apparently, upon electrochemical reduction of ultrathin films in the presence of dissolved oxygen, lanthanide bis-phthalocyaninates form intermediate complexes with it, formation of which consumes electrons that enter the film at potential of the reduction peak in the voltammogram. The electrostatic interaction of the cations from electrolyte composition (protons or $\mathrm{K}^{+}$cations) with the phthalocyaninates on electrode surface can take place via nitrogen atoms of the negatively charged macrocycle

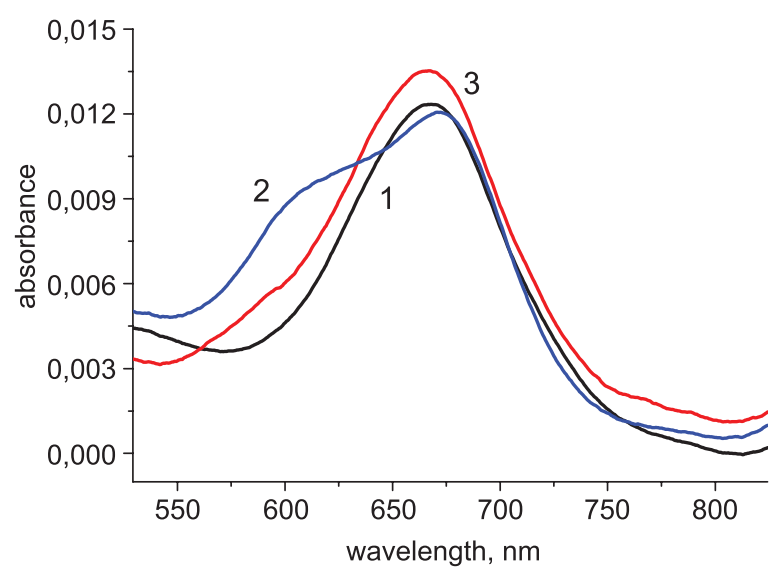

Figure 12. UV-vis spectra of the $\mathrm{Ce}\left(\mathrm{R}_{4} \mathrm{Pc}\right)_{2} \mathrm{LBF}$ in (1) electroneutral state $(+0.3 \mathrm{~V})$ and upon electrochemical reduction at potential of $-0.3 \mathrm{~V}$ in (2) open cell and (3) inert atmosphere. being reduced seems the most probable. Such interaction and spectra, similar to the ones obtained by us, was described for double-decker lanthanide phthalocyaninates in acidic solutions. ${ }^{[41,42]}$

Precise establishment of the nature and mechanism of this process requires further studies with employment of a wider set of physico-chemical methods.

\section{Conclusions}

The key role of the air oxygen in the processes of electrochemical reduction of double-decker phthalocyaninates of lanthanides in solutions and Langmuir-Blodgett films on electrode surface was revealed. Spectroelectrochemical data for both types of systems allowed us to determine the mechanism of "delay" of the reduction of the complexes in the presence of air oxygen. Such electrochemical behavior of the compounds of this class should be considered upon development of molecular devices that exploit the multistability characteristic of the tetrapyrrolic complexes.

Acknowledgements. This work was financially supported by Russian Foundation for Basic Research (grants NN 1403-32092_mol_a, 13-03-00677_a, 13-03-12473_ofi_m2).

\section{References}

1. Tsivadze A.Y. Russ. Chem. Rev. 2004, 73, 6-25.

2. Kobayashi N. Coord. Chem. Rev. 2002, 227, 129-152.

3. Nyokong T. In: Funct. Phthalocyanine Mol. Mater. (Jiang J., Ed.), Berlin: Springer Berlin Heidelberg, 2010, 135, 45-86.

4. Wöhrle D., Schnurpfeil G., Makarov S.G., Kazarin A., Suvorova O.N. Macroheterocycles 2012, 5, 191-202.

5. Ng D.K.P., Jiang J. Chem. Soc. Rev. 1997, 26, 433-442.

6. Pushkarev V.E., Tomilova L.G., Tomilov Y.V. Russ. Chem. Rev. 2008, 77, 875-907.

7. Jiang J., Ng D.K.P. Acc. Chem. Res. 2009, 42, 79-88.

8. Gorbunova Y.G., Lapkina L.A., Martynov A.G., Biryukova I.V., Tsivadze A.Y. Russ. J. Coord. Chem. 2004, 30, 245-251.

9. Basova T., Jushina I., Gürek A.G., Ahsen V., Ray A.K. J. R. Soc. Interface 2008, 5, 801-806.

10. Rodriguez-Mendez M.L., Aroca R., de Saja J.A. Chem. Mater. 1993, 5, 933-937.

11. Rodriguez-Mendez M.L., de Saja J.A. J. Porphyrins Phthalocyanines 2009, 13, 606-615.

12. de Saja J.A., Rodríguez-Méndez M.L. Adv. Colloid Interface Sci. 2005, 116, 1-11.

13. Besbes S., Plichon V., Simon J., Vaxiviere J. J. Electroanal. Chem. Interfacial Electrochem. 1987, 237, 61-68.

14. Li J., Gryko D., Dabke R.B., Diers J.R., Bocian D.F., Kuhr W.G., Lindsey J.S. J. Org. Chem. 2000, 65, 7379-7390.

15. Gryko D., Li J., Diers J.R., Roth K.M., Bocian D.F., Kuhr W.G., Lindsey J.S. J. Mater. Chem. 2001, 11, 11621180.

16. Selektor S.L., Sheinina L.S., Shokurov A. V., Raitman O.A., Arslanov V. V., Lapkina L.A., Gorbunova Y.G., Tsivadze A.Y. Prot. Met. Phys. Chem. Surfaces 2011, 47, 447-456.

17. Selektor S.L., Shokurov A. V. Prot. Met. Phys. Chem. Surfaces 2015, 51, 171-203.

18. Gorbunova Y.G., Martynov A.G., Tsivadze A.Y. Crown Substituted Phthalocyanines: from Synthesis towards Materials In: Handbook of Porphyrin Science, Vol. 24 (Kadish K., 
Smith K., Guilard R., Eds.), Singapore: World Scientific Publishing, 2012, 271-388.

19. Bian Y., Jiang J., Tao Y., Choi M.T.M., Li R., Ng A.C.H., Zhu P., Pan N., Sun X., Arnold D.P., Zhou Z.-Y., Li H.-W., Mak T.C.W., Ng D.K.P. J. Am. Chem. Soc. 2003, 125, 1225712267.

20. Nekelson F., Monobe H., Shimizu Y. Chem. Commun. 2006, 37, 3874-3876.

21. Selektor S.L., Shokurov A. V., Raitman O.A., Sheinina L.S., Arslanov V.V., Birin K.P., Gorbunova Y.G., Tsivadze A.Y., Colloid J. 2012, 74, 334-345.

22. Selektor S.L., Shokurov A.V., Arslanov V.V., Gorbunova Y.G., Birin K.P., Raitman O.A., Morote F., Cohen-Bouhacina T., Grauby-Heywang C., Tsivadze A.Y. J. Phys. Chem. C 2014, $118,4250-4258$.

23. Selector S.L., Shokurov A.V., Arslanov V.V., Gorbunova Y.G., Raitman O.A., Isakova A.A., Birin K.P., Tsivadze A.Y. Russ. J. Electrochem. 2012, 48, 218-233.

24. Selector S.L., Arslanov V.V., Gorbunova Y.G., Raitman O.A., Sheinina L.S., Birin K.P., Tsivadze A.Y. J. Porphyrins Phthalocyanines 2008, 12, 1154-1162.

25. Isago H. J. Porphyrins Phthalocyanines 2014, 18, 762-770.

26. Birin K.P., Gorbunova Y.G., Tsivadze A.Y. J. Porphyrins Phthalocyanines. 2006, 10, 931-936.

27. Birin K.P., Gorbunova Y.G., Tsivadze A.Y. Russ. J. Inorg. Chem. 2007, 52, 191-196.

28. Nefedova I.V., Gorbunova Y.G., Sakharov S.G., Tsivadze A.Y. Russ. J. Inorg. Chem. 2005, 50, 165-173.

29. Martynov A.G., Zubareva O.V., Gorbunova Y.G., Sakharov S.G., Tsivadze A.Y. Inorganica Chim. Acta 2009, 362, 11-18.
30. Stuchebryukov S.D., Selektor S.L., Silantieva D.A., Shokurov A.V. Prot. Met. Phys. Chem. Surf. 2013, 49, 189-197.

31. Ishikawa N., Okubo T., Kaizu Y. Inorg. Chem. 1999, 38, $3173-$ 3181.

32. Magdesieva T.V., Butin K.P., Yamamoto T., Tryk D.A., Fujishima A. J. Electrochem. Soc. 2003, 150, E608-E612.

33. Zhu P., Lu F., Pan N., Arnold D.P., Zhang S., Jiang J. Eur. J. Inorg. Chem. 2004, 3, 510-517.

34. Tomilova L.G., Chernykh E.V., Nikolaeva T.B., Zelentsov V.V., Luk'yanets E.A. Zh. Obsch. Khim. (J. Gen. Chem. USSR) 1984, 54, 1678-1679 (in Russ.).

35. Rodríguez-Méndez M.L., Souto J., de Saja-González J., de Saja J.A. Sensors Actuators B Chem. 1996, 31, 51-55.

36. Gorbunova Y., Rodríguez-Méndez M.L., Kalashnikova I.P., Tomilova L.G., de Saja J.A. Langmuir 2001, 17, 5004-5010.

37. Rodríguez-Méndez M.L., Gorbunova Y., de Saja J.A. Langmuir 2002, 18, 9560-9565.

38. Bardin M., Bertounesque E., Plichon V., Simon J., Ahsen V., Bekaroglu O. J. Electroanal. Chem. Interfacial Electrochem. 1989, 271, 173-180.

39. Revina A.A., Volod'ko V.V., Radyushkina K.A. Kinetika $i$ Kataliz 1990, 31, 1321-1327 (in Russ.).

40. Burdukov A.B., Vershinin M.A., Pervukhina N.V., Boguslvaskii E.G., Eltsov I.V., Shundrin L.A., Selector S.L., Shokurov A.V., Voloshin Y.Z. Inorg. Chem. Commun. 2014, 44, 183-187.

41. Martynov A., Biryukova V., Gorbunova Y., Tsivadze A.Y. Russ. J. Inorg. Chem. 2004, 49, 358-363.

42. Martynov A.G., Gorbunova Y.G., Khrapova I.V., Sakharov S.G., Tsivadze A.Y. Russ. J. Inorg. Chem. 2002, 47, 14791485 . 